\title{
Challenges and solutions for long-term permafrost borehole temperature monitoring and data interpretation
}

\author{
Rachel Luethi and Marcia Phillips \\ WSL Institute for Snow and Avalanche Research - SLF, Flüelastrasse 11, 7260 Davos Dorf, Switzerland \\ Correspondence to: Rachel Luethi (rachel.luethi@slf.ch)
}

Received: 4 March 2015 - Revised: 29 April 2016 - Accepted: 2 May 2016 - Published: 9 June 2016

\begin{abstract}
Long-term borehole temperature monitoring in mountain permafrost environments is challenging under the hostile conditions reigning in alpine environments. On the basis of data measured in the SLF borehole network we show three situations where ground temperature data should be interpreted with caution. (i) Thermistors have the tendency to drift, particularly if exposed to moisture or mechanical strain. This induces apparent warming or cooling, which can be difficult to differentiate from real ground temperature changes. Recalibration of thermistor chains is impossible if they cannot be extracted as a result of borehole deformation in creeping permafrost terrain. A solution using zero-curtain-based detection of drift and correction of data is presented. This method is however limited to the active layer, due to the lack of a reference temperature at greater depth. (ii) In contrast to drift-induced apparent warming, actual warming may be induced by natural processes or by the effects of construction activity. (iii) Control data from neighbouring boreholes are sometimes used to fill data gaps and discern drift - however these data may only underline the strong spatial variability of ground temperatures rather than provide measurement redundancy. A selection of recently observed problems regarding borehole monitoring in a hostile measurement environment are discussed, and advantages and possible drawbacks of various solutions including measurement redundancy or alternate instrumentation are presented.
\end{abstract}

\section{Introduction}

Mountain permafrost is sensitive to climate change and the resulting changes in snow cover or air temperature since ground temperatures are often close to $0{ }^{\circ} \mathrm{C}$ (e.g. Christiansen et al., 2010; Harris et al., 2003; PERMOS, 2013; Zenklusen Mutter et al., 2010). Recently increasing interest in the thermal state of permafrost is related to the construction of infrastructure (Bommer et al., 2010), rock-slope instability (e.g. Fischer et al., 2012; Gruber and Haeberli, 2007; Huggel et al., 2010; Krautblatter et al., 2013), rock glacier (e.g. Arenson et al., 2002; Kenner et al., 2014) and talus slope dynamics (e.g. Delaloye and Lambiel, 2005) and in general to natural hazards from permafrost areas (e.g. Huggel et al., 2010; Ravanel and Deline, 2011; Luethi et al., 2015).

The longest available mountain permafrost borehole temperature series worldwide is measured at Murtèl-Corvatsch rock glacier in the Eastern Swiss Alps and was started in 1987 (Haeberli et al., 1988). Nowadays the data are incorporated in the Swiss Permafrost Monitoring Network PER-
MOS (e.g. PERMOS, 2013). In addition to the borehole data in the large official permafrost monitoring networks (mainly national ones) like PERMOS, NORPERM (Juliussen et al., 2010) and several networks in North America (Smith et al., 2010), which are all incorporated in the Global Terrestrial Network for Permafrost (GTN-P; Burgess et al., 2000), there are also a number of other boreholes in which permafrost temperatures are monitored. In the Swiss Alps the latter are often located close to infrastructure and can reveal information on the influence of construction activity and infrastructure as well as on the evolution of permafrost.

Most temperature measurement series in the Alps are still too short to elicit trends but are extremely valuable for the detection of thermal processes in complex terrain (Zenklusen Mutter et al., 2010; Zenklusen Mutter and Phillips, 2012a). Borehole temperature data can also be used to enhance process understanding in combination with other measurements like borehole deformation measurements (Arenson et al., 2002), borehole logging (Scapozza et al., 2015), geophysical 
methods (e.g. Hauck et al., 2011; Hilbich et al., 2009; Krautblatter and Hauck, 2007; Vonder Mühll et al., 2000) or kinematic monitoring with continuous automatic GPS measurements or sporadically with total stations, differential GPS or terrestrial laser scanning (e.g. Delaloye et al., 2008, 2010; Kenner et al., 2014; Roer et al., 2005; Scapozza et al., 2014; Wirz et al., 2014).

The prerequisite for any form of borehole temperature data analysis is that the data are of high quality and have long-term continuity. This is a challenging objective for instruments located at exposed sites in high alpine terrain. One of the problems encountered over time with the use of thermistors is sensor drift, which induces apparent temperature changes. Average relative root mean square drift was found to be $0.19 \pm 0.08 \mu \mathrm{K}_{\text {week }}{ }^{-1}\left(9.88 \times 10^{-6} \pm 4.16 \times\right.$ $10^{-6} \mathrm{~K}$ year ${ }^{-1}$ ) in a study on the long-term stability of four commercially available glass bead thermistors (Lawton and Patterson, 2002). These authors found that positive thermistor drift is exacerbated by humidity - a ubiquitous problem in alpine environments. Borehole instruments can be subject to mechanical strain, which can also lead to erroneous data. Kreider et al. (2008) state that, in electronic devices that depend on a change of resistance, stretching of the membrane lengthens the resistive element, thereby increasing resistance. This induces an apparent decrease in the temperature registered by thermistors. It is therefore essential to be able to distinguish sensor drift from real temperature modifications to avoid making false conjectures on the state of the permafrost.

The aim of this paper is to discuss some of the challenges presented by long-term temperature measurements in boreholes in mountain permafrost - both from a technical point of view and with regard to data interpretation. Possible solutions are discussed. Examples from the SLF permafrost monitoring network are presented. Data acquisition is described, data processing is explained and selected results showing specific problems and various thermal phenomena are presented. Particular emphasis is given to apparent temperature changes caused by sensor drift and to data correction within the active layer.

\section{Data}

\subsection{Borehole temperature measurements and data access}

The SLF permafrost borehole temperature monitoring network includes 25 boreholes at 13 sites in the Swiss Alps (Fig. 1, Table 1). Nine of these are included in the Swiss Permafrost Monitoring Network (PERMOS). The others are not because they were drilled in the context of construction projects and are often close to mountain infrastructure and so not ideally suited for undisturbed permafrost monitoring with regard to climate change. The boreholes are located at elevations above approximately $2400 \mathrm{~m}$ a.s.l. and cover different landforms like crests, rock walls, talus slopes and rock glaciers with contrasting temperatures and ice contents. They are up to $53 \mathrm{~m}$ deep and the longest measurement series were started in 1996. In this paper we discuss data from the boreholes at Eggishorn, Schafberg, Matterhorn, Grächen and Arolla. The sites are briefly described in Sect. 2.2. The Schafberg and Matterhorn boreholes are part of PERMOS.

The boreholes are equipped with grouted watertight PVC tubes. The instruments are placed in watertight boxes in concrete wells and are grounded for protection against lightning. Temperatures are measured with calibrated high-precision $\left( \pm 0.01{ }^{\circ} \mathrm{C}\right) \mathrm{NTC}$ (negative temperature coefficient) Yellow Springs Instruments (YSI) 48006/8 thermistors at various depths in 2-hourly to daily resolution, and data are stored in Campbell CR10X and C1000 data loggers. Power is provided by two $12 \mathrm{~V}$ lithium batteries. All thermistors were calibrated in the laboratory at $0^{\circ} \mathrm{C}$ in ice-water mixtures before being installed.

The SLF permafrost monitoring network has been included in the research experiment platform SwissExperiment (Dawes et al., 2008; Jeung et al., 2010) in 2015. Metadata were registered in the SwissExperiment metadata wiki (http://www.swiss-experiment.ch/index.php/SLF permafrost_borehole_data). Processed data are available upon request on the internet (http://montblanc.slf.ch:22001/) via a GSN middleware (Aberer et al., 2006, 2007). It is transmitted automatically for locations where data are read out remotely and updated periodically for all other locations. PERMOS data are available online (http://dx.doi.org/10.13093/ permos-2016-01.)

\subsection{Site descriptions}

\subsubsection{Eggishorn}

The Eggishorn borehole is located at $2840 \mathrm{~m}$ a.s.l., at the base of a cable-car pylon in a steep southeast-facing scree slope. The borehole is $10.5 \mathrm{~m}$ deep and equipped with 15 YSI 44006 thermistors. It was drilled in 2008 by the cablecar company for permafrost monitoring purposes.

\subsubsection{Schafberg}

The Schafberg site has two neighbouring boreholes located on the west-facing rock glacier Foura da l'Amd Ursina above Pontresina in the Upper Engadine. They were both drilled in 1990 by VAW (ETH Zurich) and later on transferred to the SLF permafrost monitoring network in 1997 and to PERMOS in 2000. B1 at $2754 \mathrm{~m}$ a.s.l. is equipped with 16 YSI 44006 thermistors and B2 at 2732 m a.s.l. with 12 YSI 44006 thermistors.

\subsubsection{Matterhorn, Hörnli Ridge}

The Matterhorn borehole is located in a flat sector of the eastern Hörnli ridge of the mountain at $3270 \mathrm{~m}$ a.s.l., just above 
Table 1. Overview of the presented sites of the SLF permafrost borehole temperature monitoring network. An asterisk indicates boreholes which are part of the Swiss Permafrost Monitoring Network PERMOS.

\begin{tabular}{|c|c|c|c|c|c|}
\hline Site & Landform & Borehole(s) & Coordinates & $\begin{array}{l}\text { Elevation } \\
\text { (m a.s.l.) }\end{array}$ & Measurement period \\
\hline \multirow[t]{2}{*}{ Mont Dolin } & \multirow[t]{2}{*}{ talus slope } & Arolla B2 & $\begin{array}{l}46.02663^{\circ} \mathrm{N} \\
7.45473^{\circ} \mathrm{E}\end{array}$ & 2840 & $\begin{array}{l}16 \text { December } 1996 \text { to } \\
28 \text { June } 2007\end{array}$ \\
\hline & & Arolla B1 & $\begin{array}{l}46.02677^{\circ} \mathrm{N} \\
7.45487^{\circ} \mathrm{E}\end{array}$ & 2820 & $\begin{array}{l}16 \text { December } 1996 \text { to } 7 \\
\text { March } 2013\end{array}$ \\
\hline Eggishorn & talus slope & Eggishorn & $\begin{array}{l}46.42687^{\circ} \mathrm{N} \\
8.09365^{\circ} \mathrm{E}\end{array}$ & 2840 & since 27 February 2009 \\
\hline \multirow[t]{2}{*}{ Grächen } & \multirow[t]{2}{*}{ talus slope } & Grächen Grat & $\begin{array}{l}46.17642^{\circ} \mathrm{N}, \\
7.85910^{\circ} \mathrm{E}\end{array}$ & 2860 & since 18 August 2004 \\
\hline & & Grächen Berg & $\begin{array}{l}46.18694^{\circ} \mathrm{N} \\
7.86922^{\circ} \mathrm{E}\end{array}$ & 2450 & $\begin{array}{l}\text { since } 18 \text { November } \\
2002\end{array}$ \\
\hline Matterhorn & rock ridge & Hörnli Ridge B2* & $\begin{array}{l}45.98231^{\circ} \mathrm{N} \\
7.67600^{\circ} \mathrm{E}\end{array}$ & 3270 & since 8 October 2005 \\
\hline $\begin{array}{l}\text { Schafberg } \\
\text { (Ursina/VAW) }\end{array}$ & rock glacier & Schafberg B2* & $\begin{array}{l}46.49878^{\circ} \mathrm{N}, \\
9.92522^{\circ} \mathrm{E}\end{array}$ & 2732 & since 4 October 1996 \\
\hline
\end{tabular}

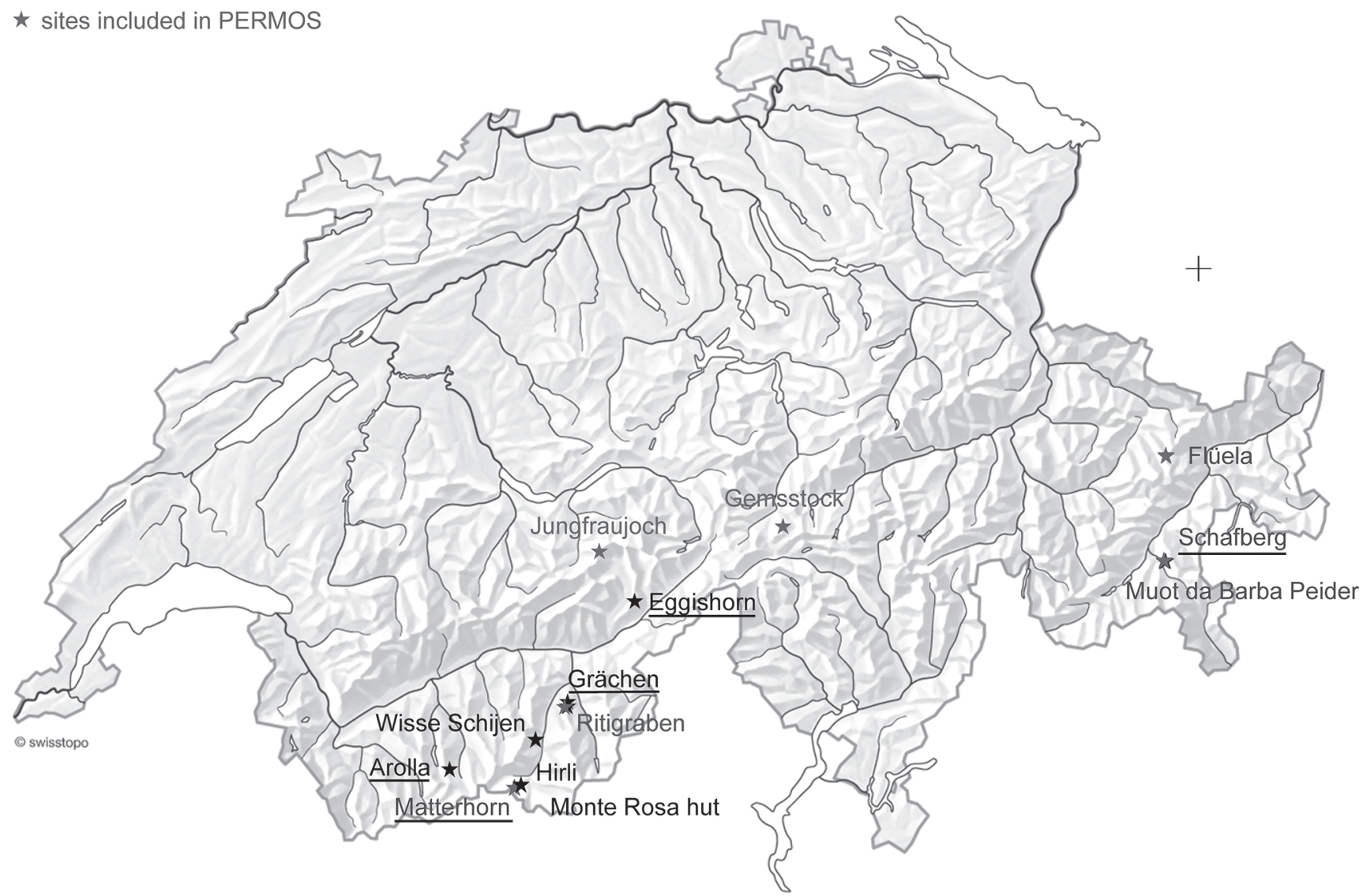

Figure 1. Map of Switzerland showing the location of the SLF permafrost monitoring boreholes (sites containing PERMOS boreholes maintained by SLF are shown in light grey). The boreholes presented in this paper have been underlined. Reproduced with the authorisation of swisstopo (K606-01). 
the Hörnli mountain hut, and is part of PERMOS. The borehole was drilled in 2005 in an attempt to find water for the hut and is $53 \mathrm{~m}$ deep. It is equipped with 15 YSI 44006 thermistors.

\subsubsection{Grächen}

Two $24 \mathrm{~m}$ deep boreholes were drilled in 2002 during the planning phase of a chairlift. They are located adjacent to the chairlift middle station on a northwest-facing talus slope at $2450 \mathrm{~m}$ a.s.l. Both boreholes are equipped with 12 YSI 44006 thermistors.

\subsubsection{Arolla, Mont Dolin}

The two $6 \mathrm{~m}$ boreholes on the eastern slope of Mont Dolin above Arolla were drilled in 1996 to monitor experimental avalanche defence structures in creeping permafrost terrain (Phillips, 2000). They are located in a scree slope at 2840 and $2820 \mathrm{~m}$ a.s.l. and both equipped with five YSI 44008 thermistors. Unfortunately the measurements in these two boreholes at Mont Dolin had to be stopped in 2013 due to the occurrence of massive rockfall over both boreholes.

\section{Methods}

\subsection{Data analysis and processing}

Borehole temperature data were carefully checked and if necessary corrected or removed but data gaps were not filled. To carry out quality controls specific processing routines were developed with R (R Development Core Team, 2011) and applied to all data. For all processed values a flag is set in the database, indicating the procedure with which the value has been changed or deleted.

\subsubsection{Data filtering}

Data were filtered on the basis of predefined minimum and/or maximum ground temperature values. Values exceeding these were deleted. Filters were applied for all sensors located at different depths. Temperature minima and maxima were chosen according to realistic values expected for a certain thermistor: if for example temperatures within the permafrost body remain below $0{ }^{\circ} \mathrm{C}$ during the whole measurement series it is not probable that single days exhibit temperatures much above $0{ }^{\circ} \mathrm{C}$, and therefore a maximum threshold of a few hundredths of a degree would be chosen. For examples where drift is visible higher thresholds have to be chosen in order to avoid losing data unnecessarily by data filtering since filtering is applied before the zero-curtain-based data correction.
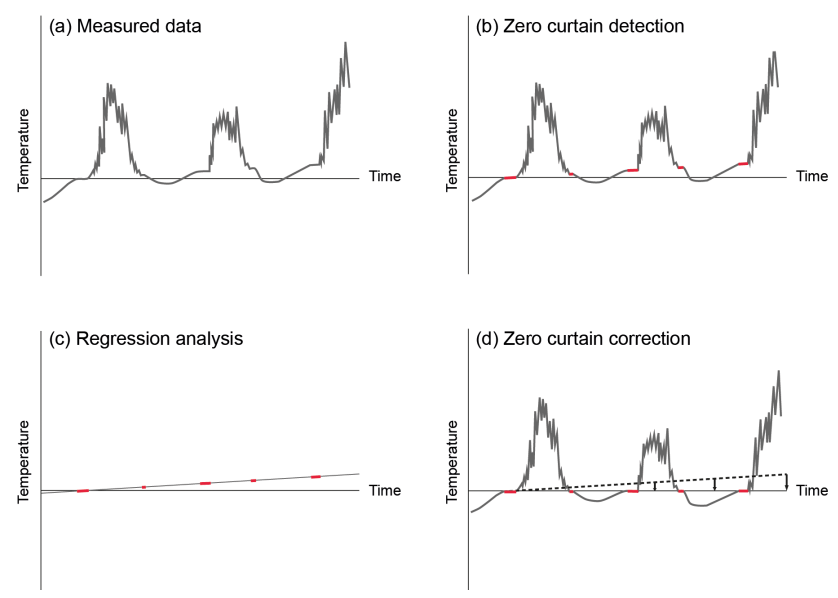

Figure 2. Schematic zero-curtain-based borehole temperature data correction.

\subsubsection{Zero-curtain-based data correction}

The zero curtain refers to the effect maintaining temperatures of freezing/thawing soils close to $0^{\circ} \mathrm{C}$ due to latent heat release during phase change (Outcalt et al., 1990). This phenomenon also occurs within the active layer of permafrost. The zero curtain is the only period during which ground temperature remains constant at $0^{\circ} \mathrm{C}$ and thus allows one to evaluate whether thermistors in the active layer are measuring correctly or undergoing sensor drift. A zero-curtain-based correction has been developed which is explained in the following and shown schematically in Fig. 2. For a zero-curtainbased correction, the spring or autumn zero curtains of the different years are first detected by applying the following criteria: (i) temperature is within a given temperature range (e.g. $>-0.5$ and $<0.5^{\circ} \mathrm{C}$ ), and (ii) the temperature gradient does not exceed a certain predetermined value. Temperature gradients are based on the absolute difference to the preceding values. Best results were obtained by calculating running means of the whole time series with a window of a few days. The detected zero curtain is checked visually and can be improved iteratively by changing the different input parameters of the function. Different regressions can be applied (linear, exponential and several polynomial regressions) to the evaluated zero curtain in order to detect and correct thermal drift. Best fit seems to be obtained by second-order polynomial functions because drift tends to start slowly and increase exponentially. Drift can attain several degrees Celsius over a period of around 5 years. Drift is only corrected for increasing fitted values because drift of temperature sensors rarely results in apparently decreasing temperatures (one exception is discussed in Sect. 4.2). Our observations show that in Alpine boreholes drift is most often caused by moisture incursion due to damaged borehole tubing, which leads to a decrease in thermal resistivity and thus to apparently increasing temperatures. 
Zero-curtain-based data correction is only possible within the active layer where phase changes at $0{ }^{\circ} \mathrm{C}$ occur. Below, sensors have to be removed for recalibration in the laboratory to ensure that measurements are correct. This is not always possible, as thermistor chains can be trapped due to borehole deformation and/or freezing of water at the base of the borehole. Observations on mechanical disturbances such as water intrusion or strain damaging the sensors help to discriminate between sensor drift and natural phenomena related to warming permafrost.

\section{Results showing selected thermal phenomena registered in boreholes}

In the following subsections, selected processes observed in mountain permafrost and various problems and solutions regarding measurement techniques are discussed on the basis of temperature data measured in different boreholes in the SLF permafrost monitoring network. The phenomena shown include apparent warming due to sensor drift, apparent cooling caused by the stretching of thermistor cables, actual permafrost degradation caused by construction activity and unexpected contrasts in ground temperature over short distances. These examples have been chosen because they represent typical challenges in the context of borehole temperature monitoring at present.

\subsection{Apparent warming induced by sensor drift}

Apparent warming induced by sensor drift was observed in boreholes at Eggishorn and Schafberg. The application of zero-curtain-based data correction is shown, and its influence on active layer thickness (ALT) is evaluated.

\subsubsection{Eggishorn}

Borehole temperature measurements from early 2009 onwards indicated that the active layer was $6 \mathrm{~m}$ thick. In summer 2011 sudden permafrost degradation occurred to the base of the borehole (Fig. 3a), and the active layer did not freeze back completely in winter 2011/2012. This abrupt warming to $10.5 \mathrm{~m}$ depth seemed suspicious, so the thermistor chain was recalibrated and found to be defect, as it registered positive temperatures (several tenths of a degree Celsius) in a $0^{\circ} \mathrm{C}$ ice-water mixture. Dissection of the thermistor chain in the laboratory revealed that water had caused damage to the thermistors, leading to sensor drift and thus to apparently increasing ground temperatures. Lawton and Patterson (2002) confirm that humidity adversely affects thermistor stability. The thermistor chain was replaced, as was the logger and special waterproofing measures were taken (e.g. additional heat shrink tubing) to protect the sensors against renewed water infiltration.

In an attempt to reconstruct the temperature regime within the active layer during the period when the thermistors were faulty, the zero-curtain-based correction explained in Sect. 3.2.2 was applied. Ground temperatures were corrected for all sensors to a depth of $5 \mathrm{~m}$, i.e. within the active layer with the parameters specified in Table 2. Temperature data below were removed after the date at which the sensors within the active layer exhibited temperature drift for the first time. Visual inspection of the measured data clearly indicates that drift was also occurring below the active layer. Comparison of the thermal contour plot of raw temperature data with the plot showing the processed data (Fig. 3) shows that the correction of ground temperatures to the order of $0.1^{\circ} \mathrm{C}$ or even less results in significant changes in the interpretation of active layer duration. This is due to the fact that temperature gradients in the profile are low and ground temperatures are close to $0^{\circ} \mathrm{C}$. This method allowed cutting data loss to a certain extent within the active layer. Continued measurements with the new thermistor chain will help to understand the processes occurring in this warm permafrost substrate.

\subsubsection{Schafberg}

Borehole 2 (located at 2754 ma.s.1.) exhibited drift from 2010 onwards, so the thermistor chain was replaced in 2013. Analogous to Eggishorn (Sect. 4.1.1) zero-curtain correction has been applied with second-order polynomial regression in order to reconstruct borehole temperature data prior to 2013. The values of the used parameters are specified in Table 2. Processed borehole temperature data at 2 and $3 \mathrm{~m}$ depth are shown in Fig. 4. Using these processed data, annual maximum active layer thicknesses have been calculated (Fig. 5). Even though they do not represent true temperatures and sensors below the active layer cannot be corrected, they give an indication on the evolution of the temperatures in the active layer.

\subsection{Apparent cooling induced by stretching of thermistor cables}

The instruments in boreholes in mountain permafrost can undergo strong lateral deformation (e.g. due to the presence of shear horizons) leading to thermistor loss through shearing (Zenklusen and Phillips, 2012b). Borehole instruments can also be subject to longitudinal deformation, caused by ground subsidence or mechanical strain. Stretching of thermistor cables lengthens the resistive element, thereby increasing resistance (Kreider et al., 2008). This causes an apparent decrease in ground temperature when using NTC thermistors.

The Matterhorn borehole data shows initial warming followed by decreasing temperatures at depths significantly below the active layer (Fig. 6), particularly between 20 and $40 \mathrm{~m}$ depth. This phenomenon started after snowmelt washed fine-grained material into the borehole tubing in July 2008, making it impossible to extract the thermistors thereafter. This "cementing" of the tube may have induced stretching 
(a) Eggishorn - raw data

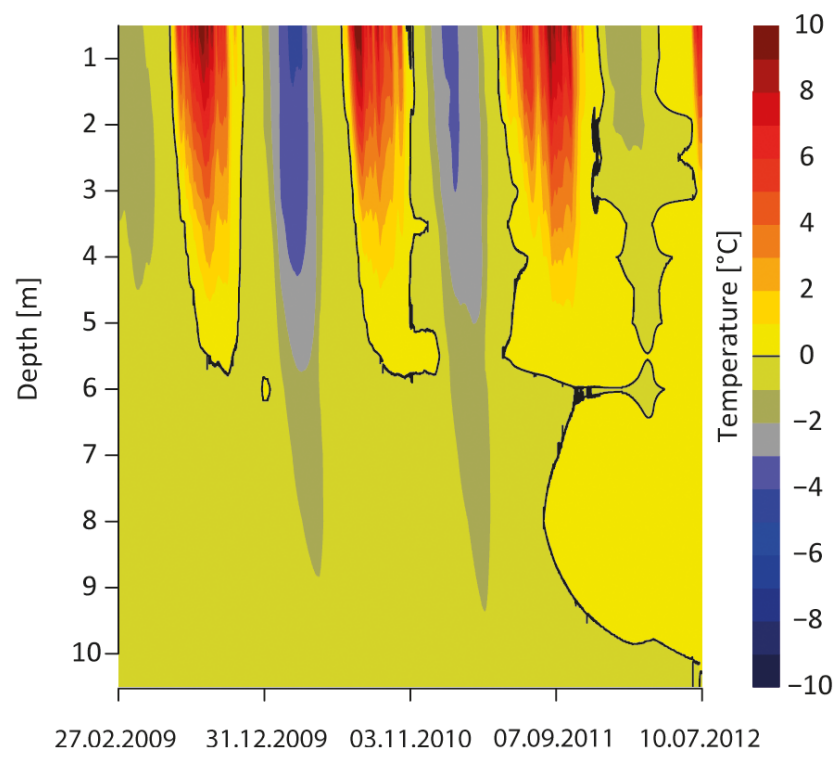

(b) Eggishorn - processed data

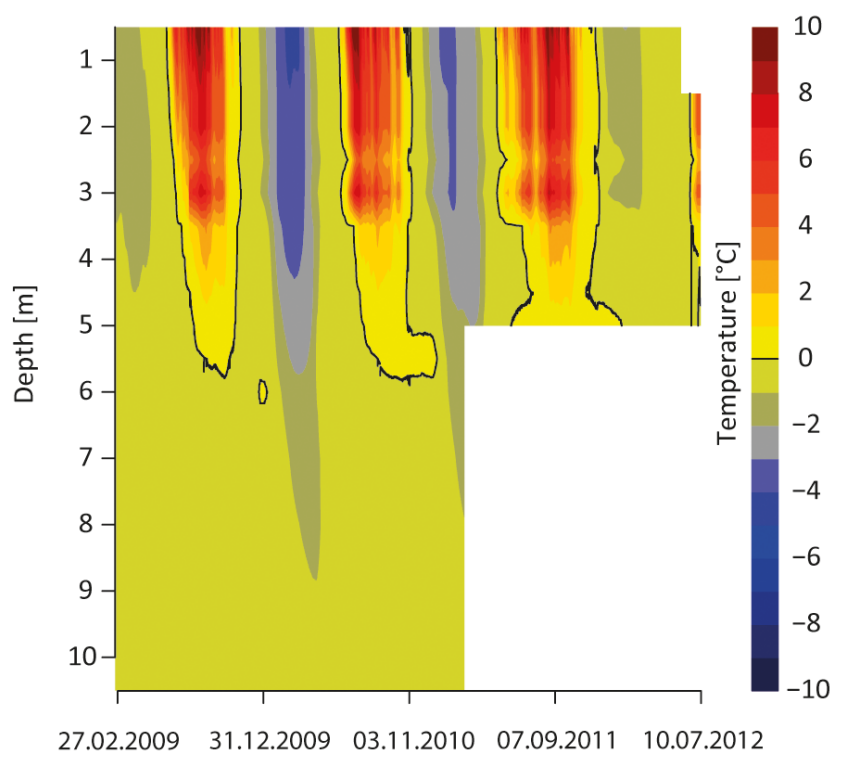

Figure 3. Contour plots of measured borehole temperature data at Eggishorn at several depths (a) and the corresponding zero-curtaincorrected ground temperatures and removed data for unverifiable values measured below the active layer (b).

Table 2. Values used for the zero-curtain-based borehole temperature correction for Eggishorn and Schafberg B1.

\begin{tabular}{lrrrll}
\hline Borehole & Depth $(\mathrm{m})$ & $\begin{array}{r}\text { Temperature } \\
\text { range }\left({ }^{\circ} \mathrm{C}\right)\end{array}$ & $\begin{array}{r}\text { Temperature } \\
\text { gradient }\left({ }^{\circ} \mathrm{C}\right)\end{array}$ & $\begin{array}{l}\text { Window of } \\
\text { running mean }\end{array}$ & $\begin{array}{l}\text { Correction } \\
\text { method }\end{array}$ \\
\hline Eggishorn & 0.5 & $-0.15-0.25$ & 0.003 & $40 \mathrm{~h}$ & exponential \\
& 1.0 & $-0.18-0.15$ & 0.0006 & $80 \mathrm{~h}$ & exponential \\
& 1.5 & $-0.2-0.3$ & 0.0015 & $40 \mathrm{~h}$ & second-order polynomial \\
& 2.0 & $-0.2-0.3$ & 0.0015 & $40 \mathrm{~h}$ & second-order polynomial \\
& 2.5 & $-0.3-0.1$ & 0.0015 & $40 \mathrm{~h}$ & second-order polynomial \\
& 3.0 & $-0.2-0.3$ & 0.0015 & $40 \mathrm{~h}$ & second-order polynomial \\
& 3.5 & $-0.05-0.5$ & 0.0008 & $40 \mathrm{~h}$ & second-order polynomial \\
& 4.0 & $-0.1-0.2$ & 0.0005 & $40 \mathrm{~h}$ & second-order polynomial \\
& 4.5 & $-0.1-0.5$ & 0.0005 & $40 \mathrm{~h}$ & second-order polynomial \\
& 5.0 & $-0.1-0.045$ & 0.0001 & $50 \mathrm{~h}$ & second-order polynomial \\
\hline Schafberg B1 & 2.0 & $-0.3-0.25$ & 0.005 & 15 days & second-order polynomial \\
& 3.0 & $-0.05-0.3$ & 0.005 & 20 days & second-order polynomial \\
& 4.0 & $-0.3-0.25$ & 0.005 & 15 days & second-order polynomial \\
\hline
\end{tabular}

of some thermistor cables, causing the apparent temperature decrease registered since 2008. Due to the lack of a reference temperature at depth, it is not possible to correct these data.

\subsection{Warming induced by construction activity}

Construction activity in mountain permafrost can influence both ground temperature and ice content (Bommer et al., 2010) and eventually lead to mass movements (e.g. Ravanel et al., 2013) or to creep and/or subsidence due to warming and ice loss. These processes can affect the geometry of infrastructure, causing damage and substantially shortening its design life. As a result, specially adapted technical measures and construction materials need to be used in substrates with negative ground temperatures - and wherever possible, icerich ground should be avoided (Bommer et al., 2009). Highquality borehole temperature measurements are therefore essential in the planning phase of mountain infrastructure.

Temperature measurements in the two boreholes near the intermediate station of a chairlift at $2450 \mathrm{~m}$ a.s.l. above Grächen show the rapid degradation of permafrost since 2003 , following the formation of a supra-permafrost talik in place of the active layer and massive intra-permafrost talik 

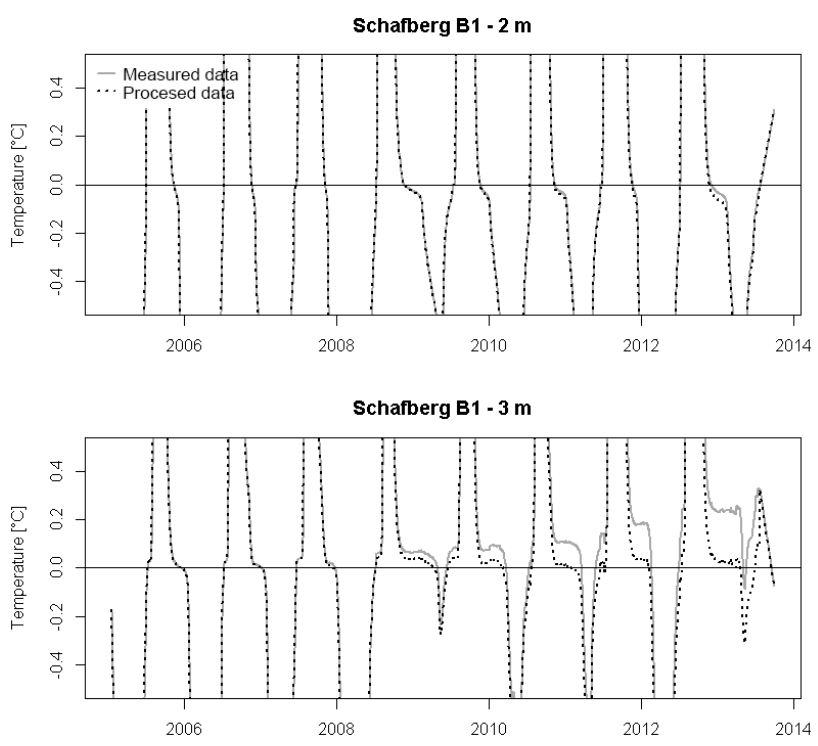

Figure 4. Measured and processed borehole temperature data at 2 and $3 \mathrm{~m}$ depth (in the active layer) at Schafberg B1.

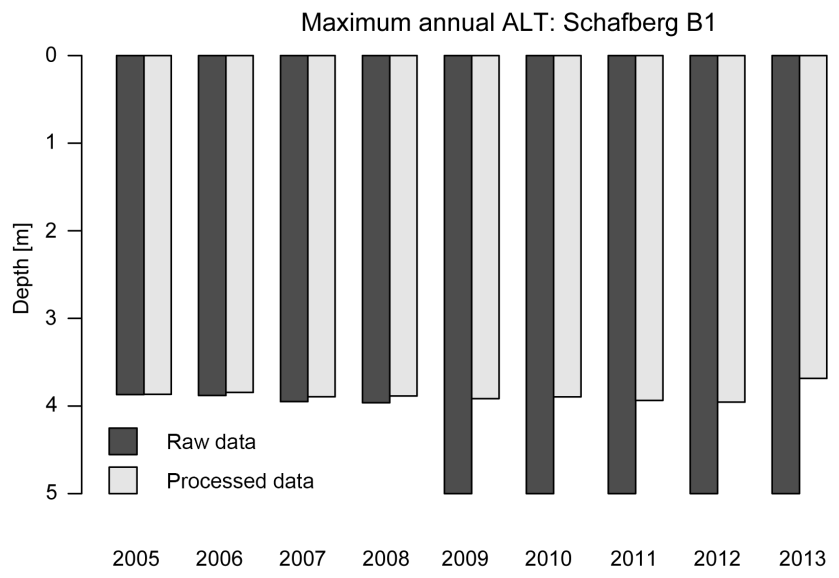

Figure 5. Maximum annual active layer thicknesses of raw and processed borehole temperature data at Schafberg B1.

formation (Fig. 7). This rapid thawing can be attributed to the construction of the chairlift midway station during the exceptionally hot summer 2003, when a large pit had to be excavated for the foundations. The structure was specifically designed for this site: it is flexible and its three-point geometry can constantly be adapted to the changing substrate conditions inducing subsidence during ice loss (Phillips et al., 2006). The credibility of the borehole temperature data at this site is underlined by the fact that the permafrost degradation was registered in two boreholes simultaneously, underlining the utility of redundant measurements. In addition, data measured in boreholes within a radius of a few hundred metres (Ritigraben and Seetalhorn) helped to confirm that the permafrost thaw described above was very local and can be attributed to the influence of the construction activity.

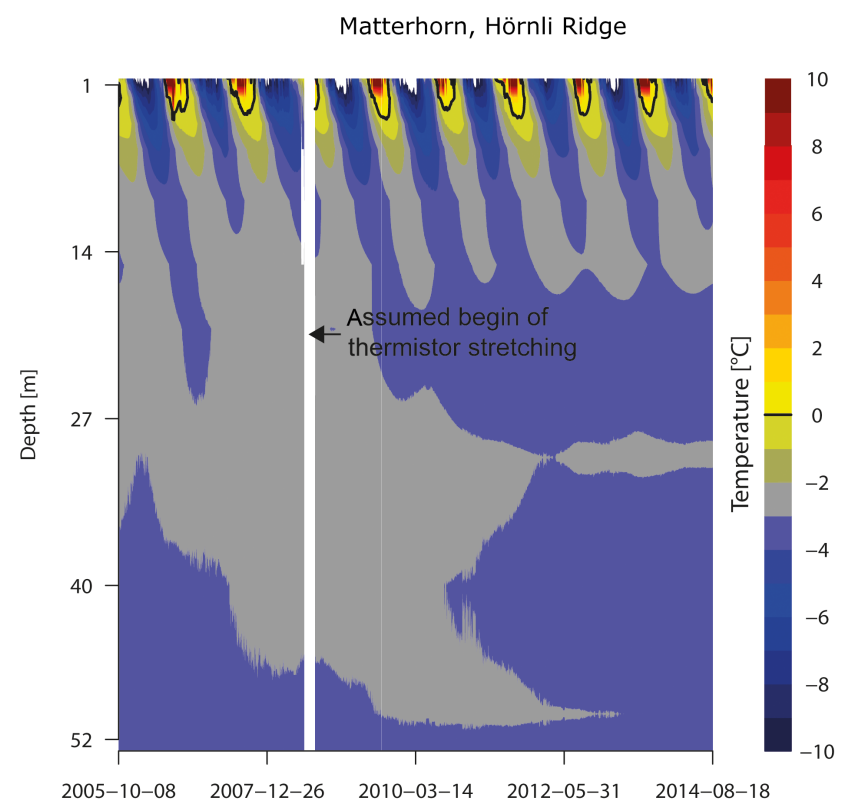

Figure 6. Contour plot of ground temperatures in the Matterhorn, Hörnli Ridge, borehole with apparent cooling effects at depth.

Measurements carried out in boreholes located close to each other can be useful to identify technical problems such as sensor drift or unexpected thermal anomalies, caused for example by air or water fluxes within the ground, which could otherwise be interpreted as measurement errors themselves. In contrast, they sometimes also allow one to discern the high spatial variability of ground temperature in mountainous terrain over short distances.

\subsection{Contrasting ground temperatures over short distances}

Temperature measurements in two $6 \mathrm{~m}$ boreholes on the eastern slope of Mont Dolin above Arolla are shown in Fig. 8. Surprising contrasts in ground temperature can be observed here over a very short distance. Permafrost is completely absent in borehole B1, which is only affected by seasonal frost to varying depths (depending on the depth and duration of the winter snow cover) and remains unfrozen the remainder of the year. In contrast, permafrost is present in borehole B2, which is only $30 \mathrm{~m}$ away but higher up on the slope. The permafrost appears to be quite ice-rich here, as active layer thickness remained rather constant at around $2.5 \mathrm{~m}$ depth over the measurement period between 1996 and 2011, whereas active layers thickened in other talus slopes in the Swiss Alps during this period (e.g. during the 2003 heat wave) (PERMOS, 2007). High ice contents below the active layer typically lead to constant active layer thicknesses due to the latent heat required to melt ice (Zenklusen Mutter and Phillips, 2012a). 


\section{(a)Grächen Berg}

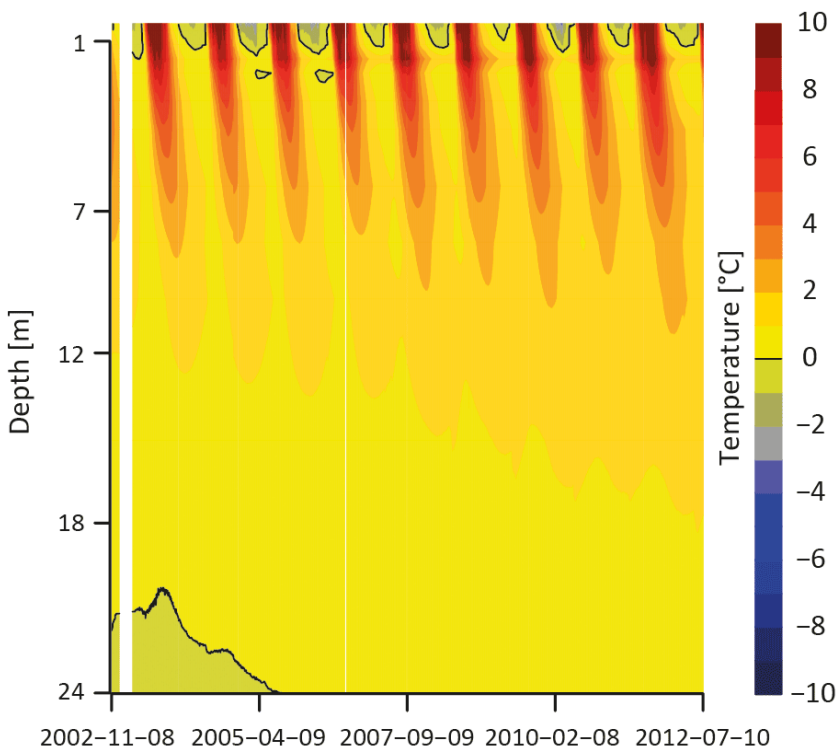

(b) Grächen Tal

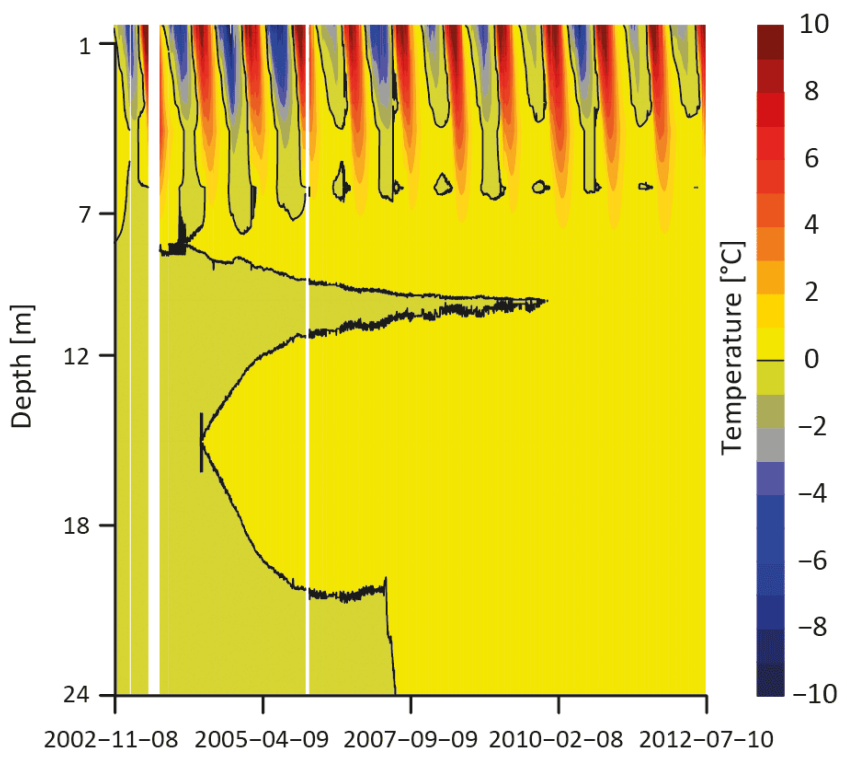

Figure 7. Contour plots of ground temperatures in two boreholes at the intermediate station of a chairlift above Grächen showing permafrost degradation at depth (a) and supra-permafrost and intra-permafrost talik formation leading to permafrost degradation (b).

\section{Discussion}

Over the years various technical challenges related to the measurement of ground temperature in boreholes have become apparent and have been solved with technical solutions and/or the post-processing of thermal data. Measurement uncertainties of high-precision thermistors are of the order of a few hundredths of a degree when thermistors are calibrated on a regular basis. However, in Alpine permafrost, recalibration is often impossible because thermistors are blocked in the borehole tube due to borehole deformation caused by creep and shearing of the permafrost substrate. It can therefore be assumed that effective precision may be reduced with time, which is a problem for long-term measurements. Not being able to recalibrate thermistors leads to a further challenge, namely in distinguishing between actually occurring processes (e.g. permafrost warming) and sensor drift. In addition, for logistical, technical and financial reasons most borehole data are only retrieved on-site once or twice a year, which results in huge data losses in the event of technical problems. Drift is often not immediately detected unless it results in an obvious suspicious increase in temperatures (e.g. induced by water damage to the sensors), as was registered at Eggishorn - however lateral water/air fluxes at depth can lead to similar "suspicious" temperature data but are a naturally occurring phenomenon of particular interest. Observations of such lateral disturbances in mountain permafrost - caused by water (Zenklusen and Phillips, 2012b) or air fluxes (Phillips et al., 2009) - have increased recently. Less dramatic sensor drift is often only detected after several years, making it all the more difficult to discriminate between sensor drift and ac- tually occurring processes. The presented zero-curtain-based data correction may help to reduce data loss by the detection of sensor drift in advance and by correcting drifting temperatures. Nevertheless every processing routine contains some uncertainties - that is, the possibility of not detecting the zero curtain or detecting a wrong zero curtain.

Long-term cooling is more suspicious under the present climate conditions. The coincident occurrence of mechanical disturbance and persistent cooling in the Matterhorn borehole makes it doubly suspicious, and it probably has to be attributed to stretching of thermistor cables.

Despite being extremely expensive and logistically challenging, measurement redundancy (i.e. the drilling of two boreholes per site rather than one) allows one to discern natural processes such as lateral air/water fluxes, to observe ground temperature contrasts over short distances and to detect the occurrence of sensor drift. However the Mont Dolin example shows that measurement redundancy can also unexpectedly reveal contrasting ground temperatures over very short distances, which is of interest but cancels the actual aim of carrying out "control" measurements in adjacent boreholes.

The borehole data shown here underline the fact that changes can occur at unpredictable depths in the ground and thermistors have the limitation of being located at predefined depths. The ideal measurement technique in changing mountain permafrost substrates would be fibre-optic distributed temperature sensing (DTS) since it allows one to measure temperatures over the whole length of the borehole and thus discern variations at any depth. However at present, first tests (not shown here) using DTS in the laboratory and in our 
(a) Arolla B1

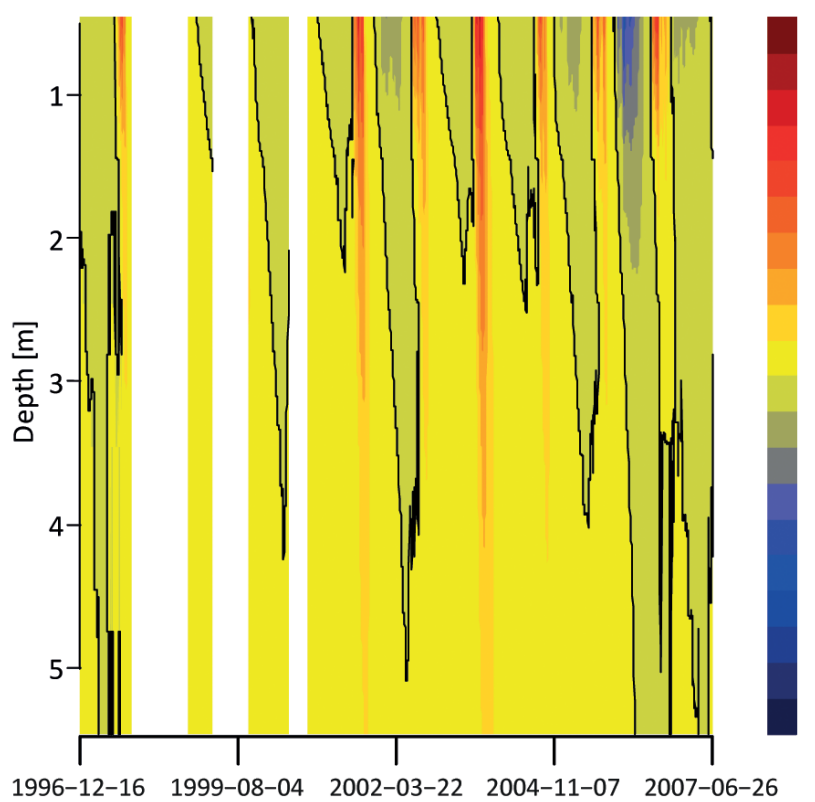

(b) Arolla B2

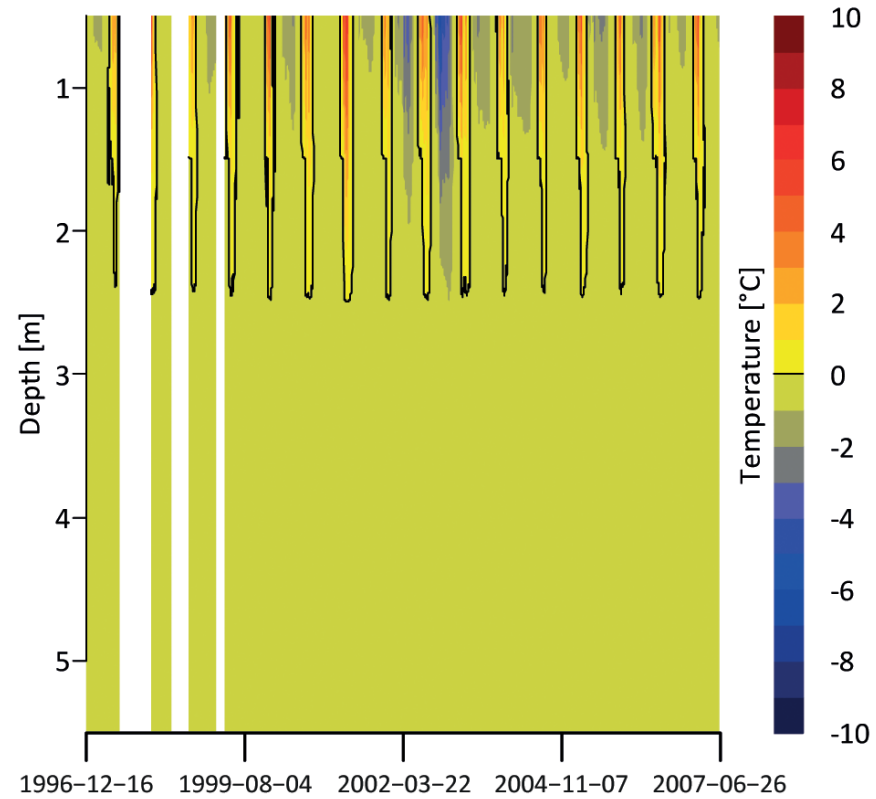

Figure 8. Contour plots of the ground temperatures in two boreholes at Mont Dolin, Arolla. Borehole B1 (a) is not in permafrost whereas $\mathrm{B} 2(\mathbf{b})$ is.

boreholes have shown that there is too much measurement noise and the accuracy of the system $\left(0.2^{\circ} \mathrm{C}\right)$ is not yet high enough to register temperature changes smaller than $0.02{ }^{\circ} \mathrm{C}$, which is crucial for example in the detection of water during talik formation (Zenklusen and Phillips, 2012b). In addition, the system has a high energy consumption and is far too bulky to fit into conventional concrete shafts - which are essential for protection against rockfall and avalanches.

The SLF borehole temperature monitoring network has not only proven useful to measure the long-term evolution of permafrost - it also delivers valuable information on natural and artificial factors influencing temperature and ice content in mountain permafrost. The latter can for example be derived from borehole drilling logs or cores. The data obtained are also essential for calibrating and validating numerical simulations (e.g. Haberkorn et al., 2015a, b; Magnin et al., 2015; Noetzli et al., 2010).

\section{Conclusions}

Long-term temperature monitoring in boreholes is carried out to detect the influences of the climate and of local conditions such as snow cover depth and duration on the thermal state of permafrost. However, data must be interpreted with care, as thermistors can be subject to drift if they are exposed to moisture or their cables are damaged. Thermistors should therefore be recalibrated regularly. However, in creeping mountain permafrost thermistor chains are often blocked in the boreholes or frozen to the tube, preventing recalibration. Using specially developed $\mathrm{R}$ functions we showed that semi-automatic zero-curtain-based drift detection and correction are possible for data measured within the active layer thanks to the bi-annual occurrence of $0{ }^{\circ} \mathrm{C}$ for prolonged periods, but not below, due to the lack of a reference temperature. Measurement redundancy is very useful to detect measurement errors, natural phenomena such as lateral water/air flow or the influence of infrastructure. However, redundancy can also reveal strongly contrasting ground conditions over short distances (permafrost/no permafrost) and thus could no longer be useful in this respect. An alternate measurement system using distributed temperature sensing which is not subject to drift would be ideal to measure temperatures over the entire length of a borehole, but the required accuracy has not yet been attained and the hardware is not yet suitable for hostile field conditions.

The following phenomena or combinations of these were observed in selected boreholes of the SLF monitoring network: (i) moisture-induced sensor drift leading to apparent warming; (ii) mechanically strained cables, causing apparent cooling; (iii) evidence of the influence of construction activity; and (iv) contrasting ground temperatures over short distances.

These examples underline that great care must be taken in the measurement design, the analysis and interpretation of long-term borehole temperature data as well as in the maintenance of the measurement infrastructure. 


\section{Data availability}

Data are available from the Swiss Permafrost Monitoring Network Database (PERMOS Database) of the Swiss Permafrost Monitoring Network (PERMOS) http://dx.doi.org/ 10.13093/permos-2016-01.

\section{The Supplement related to this article is available online at doi:10.5194/gh-71-121-2016-supplement.}

Acknowledgements. We thank M. Hiller, the SLF electronics group and mechanical workshop as well as all field assistants for support with field work and measurement equipment. N. Dawes and J. Caduff-Fiddes are thanked for their support with SwissExperiment. We kindly acknowledge Canton Valais and Canton Grisons as well as all borehole owners (Bergbahnen Grächen, Burgergemeinde Zermatt, Luftseilbahn Fiesch-Eggishorn). Two of the SLF boreholes presented are incorporated in PERMOS. The quality of non-PERMOS SLF borehole temperature data was improved within the scope of the IQUASAP (Improving Quality and Availability of high alpine Snow and Permafrost data) project funded by CCES (Competence Center Environment and Sustainability of the ETH Zurich). We warmly thank the editor, Martin Hoelzle, as well as Benno Staub and an anonymous reviewer for their constructive feedback.

Edited by: M. Hoelzle

Reviewed by: two anonymous referees

\section{References}

Aberer, K., Hauswirth, M., and Salehi, A.: A middleware for fast and flexible sensor network deployment, Proceedings of the 32nd international conference on very large data bases, Seoul, Korea, 1199-1202, 2006.

Aberer, K., Hauswirth, M., and Salehi, A.: Infrastructure for Data Processing in Large-Scale Interconnected Sensor Networks, International Conference on Mobile Data Management 2007, 198205, doi:10.1109/mdm.2007.36, 2007.

Arenson, L., Hoelzle, M., and Springman, S.: Borehole deformation measurements and internal structure of some rock glaciers in Switzerland, Permafrost Periglacial Process., 13, 117-135, doi:10.1002/ppp.414, 2002.

Bommer, C., Phillips, M., Keusen, H. R., and Teysseire, P.: Bauen im Permafrost: Ein Leitfaden für die Praxis, WSL-Institut für Schnee- und Lawinenforschung SLF, 2009.

Bommer, C., Phillips, M., and Arenson, L. U.: Practical recommendations for planning, constructing and maintaining infrastructure in mountain permafrost, Permafrost Periglacial Process., 21, 97104, doi:10.1002/ppp.679, 2010.

Burgess, M., Smith, S., Brown, J., Romanovsky, V., and Hinkel, K.: The Global Terrestrial Network for Permafrost (GTNet-P): permafrost monitoring contributing to global climate observations, Current Research 2000-E14, 1-8, 2000.
Christiansen, H. H., Etzelmüller, B., Isaksen, K., Juliussen, H., Farbrot, H., Humlum, O., Johansson, M., Ingeman-Nielsen, T., Kristensen, L., and Hjort, J.: The thermal state of permafrost in the nordic area during the international polar year 2007-2009, Permafrost Periglacial Process., 21, 156-181, doi:10.1002/ppp.687, 2010.

Dawes, N., Kumar, K. A., Michel, S., Aberer, K., and Lehning, M.: Sensor Metadata Management and Its Application in Collaborative Environmental Research, Fourth IEEE International Conference on eScience, 143-150, doi:10.1109/eScience.2008.27, 2008.

Delaloye, R. and Lambiel, C.: Evidences of winter ascending air circulation throughout talus slopes and rock glaciers situated in the lower belt of alpine discontinuous permafrost (Swiss Alps), Norsk geogr. Tidsskr., 59, 194-201, doi:10.1080/00291950510020673, 2005.

Delaloye, R., Perruchoud, E., Avian, M., Kaufmann, V., Bodin, X., Hausmann, H., Ikeda, A., Kääb, A., Kellerer-Pirklbauer, A., Krainer, K., Lambiel, C., Mihajlovic, D., Staub, B., Roer, I., and Thibert, E.: Recent interannual variations of rock glacier creep in the European Alps, 9th International Conference on Permafrost Fairbanks, Alaska, 343-348, 2008.

Delaloye, R., Lambiel, C., and Gärtner-Roer, I.: Overview of rock glacier kinematics research in the Swiss Alps, Geogr. Helv., 65, 135-145, doi:10.5194/gh-65-135-2010, 2010.

Fischer, L., Purves, R. S., Huggel, C., Noetzli, J., and Haeberli, W.: On the influence of topographic, geological and cryospheric factors on rock avalanches and rockfalls in high-mountain areas, Nat. Hazards Earth Syst. Sci., 12, 241-254, doi:10.5194/nhess12-241-2012, 2012.

Gruber, S. and Haeberli, W.: Permafrost in steep bedrock slopes and its temperature-related destabilization following climate change, J. Geophys. Res., 112, F02S18, doi:10.1029/2006JF000547, 2007.

Haberkorn, A., Phillips, M., Kenner, R., Gallos, S., Rhyner, H., Bavay, M., and Hoelzle, M.: Thermal Regime of Rock and its Relation to Snow Cover in Steep Alpine Rock Walls: Gemsstock, Central Swiss Alps, Geogr. Ann. Ser. A-phys. Geogr., 97, 579597, doi:10.1111/geoa.12101, 2015a.

Haberkorn, A., Hoelzle, M., Phillips, M., and Kenner, R.: Snow as a driving factor of rock surface temperatures in steep rough rock walls, Cold Reg. Sci. Technol., 118, 64-75, doi:10.1016/j.coldregions.2015.06.013, 2015b.

Haeberli, W., Huder, J., Keusen, H. R., Pica, J., and Röthlisberger, H.: Core drilling through rock-glacier permafrost, Tapir, Trondheim, 937-942, 1988.

Harris, C., Vonder Mühll, D., Isaksen, K., Haeberli, W., Sollid, J. L., King, L., Holmlund, P., Dramis, F., Guglielmin, M., and Palacios, D.: Warming permafrost in European mountains, Glob. Planet. Chang., 39, 215-225, doi:10.1016/j.gloplacha.2003.04.001, 2003.

Hauck, C., Böttcher, M., and Maurer, H.: A new model for estimating subsurface ice content based on combined electrical and seismic data sets, The Cryosphere, 5, 453-468, doi:10.5194/tc5-453-2011, 2011.

Hilbich, C., Marescot, L., Hauck, C., Loke, M. H., and Mäusbacher, R.: Applicability of electrical resistivity tomography monitoring to coarse blocky and ice-rich permafrost landforms, Permafrost Periglacial Process., 20, 269-284, doi:10.1002/ppp.652, 2009. 
Huggel, C., Salzmann, N., Allen, S., Caplan-Auerbach, J., Fischer, L., Haeberli, W., Larsen, C., Schneider, D., and Wessels, R.: Recent and future warm extreme events and highmountain slope stability, Philos. Trans. R. Soc. A: Mathematical, Physical and Engineering Sciences, 368, 2435-2459, doi:10.1098/rsta.2010.0078, 2010.

Jeung, H., Sarni, S., Paparrizos, I., Sathe, S., Aberer, K., Dawes, N., Papaioannou, T. G., and Lehning, M.: Effective Metadata Management in Federated Sensor Networks, Newport Beach, CA, USA, 7-9 June 2010, 107-114, doi:10.1109/SUTC.2010.29, 2010

Juliussen, H., Christiansen, H. H., Strand, G. S., Iversen, S., Midttømme, K., and Rønning, J. S.: NORPERM, the Norwegian Permafrost Database - a TSP NORWAY IPY legacy, Earth Syst. Sci. Data, 2, 235-246, doi:10.5194/essd-2-235-2010, 2010.

Kenner, R., Bühler, Y., Delaloye, R., Ginzler, C., and Phillips, M.: Monitoring of high alpine mass movements combining laser scanning with digital airborne photogrammetry, Geomorphology, 206, 492-504, doi:10.1016/j.geomorph.2013.10.020, 2014.

Krautblatter, M. and Hauck, C.: Electrical resistivity tomography monitoring of permafrost in solid rock walls, J. Geophys. Res.Earth Surf., 112, F02S20, doi:10.1029/2006jf000546, 2007.

Krautblatter, M., Funk, D., and Günzel, F. K.: Why permafrost rocks become unstable: a rock-ice-mechanical model in time and space, Earth Surf. Process. Landf., 38, 876-887, doi:10.1002/esp.3374, 2013.

Kreider, J. F., Claridge, D. E., and Culp, C. H.: Heating, Ventilating and Air Conditioning Control Systems, in: Energy management and conservation handbook, edited by: Kreith, F. and Goswami, D. Y., CRC Press, Taylor \& Francis Group, Boca Raton FL, 2008.

Lawton, K. M. and Patterson, S. R.: Long-term relative stability of thermistors: Part 2, Precision Engineering, 26, 340-345, doi:10.1016/S0141-6359(02)00110-1, 2002.

Luethi, R., Gruber, S., and Ravanel, L.: Modelling transient ground surface temperatures of past rockfall events: towards a better understanding of failure mechanisms in changing periglacial environments, Geogr. Ann. Ser. A-phys. Geogr., 97, 753-767, doi:10.1111/geoa.12114, 2015.

Magnin, F., Deline, P., Ravanel, L., Noetzli, J., and Pogliotti, P.: Thermal characteristics of permafrost in the steep alpine rock walls of the Aiguille du Midi (Mont Blanc Massif, 3842 m a.s.l), The Cryosphere, 9, 109-121, doi:10.5194/tc-9-109-2015, 2015.

Nötzli, J., Gruber, S., and von Poschinger, A.: Modellierung und Messung von Permafrosttemperaturen im Gipfelgrat der Zugspitze, Deutschland, Geogr. Helv., 65, 113-123, doi:10.5194/gh-65-113-2010, 2010.

Outcalt, S. I., Nelson, F. E., and Hinkel, K. M.: The zerocurtain effect: Heat and mass transfer across an isothermal region in freezing soil, Water Resour. Res., 26, 1509-1516, doi:10.1029/WR026i007p01509, 1990.

PERMOS: Permafrost in Switzerland 2008/2009 and 2009/2010, University of Zurich, Zurich, 80 pp., 2013.

Phillips, M.: Influences of snow-supporting structures on the thermal regime of the ground in alpine permafrost terrain, 2000, $\mathrm{PhD}$ Thesis, WSL Institute of Snow and Avalanche Research SLF, Davos, Switzerland, 146 pp., 2000.
Phillips, M.: Avalanche defence strategies and monitoring of two sites in mountain permafrost terrain, Pontresina, Eastern Swiss Alps., Nat. Hazards, 39, 353-379, doi:10.1007/s11069-0056126-x, 2006.

Phillips, M., Zenklusen Mutter, E., Kern-Luetschg, M., and Lehning, M.: Rapid degradation of ground ice in a ventilated talus slope: Flüela Pass, Swiss Alps, Permafrost Periglacial Process. 20, 1-14, doi:10.1002/ppp.638, 2009.

Ravanel, L. and Deline, P.: Climate influence on rockfalls in highAlpine steep rockwalls: The north side of the Aiguilles de Chamonix (Mont Blanc massif) since the end of the 'Little Ice Age', The Holocene, 21, 357-365, doi:10.1177/0959683610374887, 2011.

Ravanel, L., Deline, P., Lambiel, C., and Vincent, C.: Instability of a High Alpine Rock Ridge: the Lower Arête Des Cosmiques, Mont Blanc Massif, France, Geogr. Ann. Ser. A-phys. Geogr., 95, 5166, doi:10.1111/geoa.12000, 2013.

R Development Core Team: R: A Language and Environment for Statistical Computing. R Foundation for Statistical Computing, Vienna, Austria, 2011.

Roer, I., Kääb, A., and Dikau, R.: Rockglacier acceleration in the Turtmann valley (Swiss Alps): Probable controls, Norsk geogr. Tidsskr., 59, 157-163, doi:10.1080/00291950510020655, 2005.

Scapozza, C., Lambiel, C., Bozzini, C., Mari, S., and Conedera, M.: Assessing the rock glacier kinematics on three different timescales: a case study from the southern Swiss Alps, Earth Surf. Process. Landf., 39, 2056-2069, doi:10.1002/esp.3599, 2014.

Scapozza, C., Baron, L., and Lambiel, C.: Borehole Logging in Alpine Periglacial Talus Slopes (Valais, Swiss Alps), Permafrost Periglacial Process., 26, 67-83, doi:10.1002/ppp.1832, 2015.

Smith, S. L., Romanovsky, V. E., Lewkowicz, A. G., Burn, C. R., Allard, M., Clow, G. D., Yoshikawa, K., and Throop, J.: Thermal state of permafrost in North America: a contribution to the international polar year, Permafrost Periglacial Process., 21, 117-135, doi:10.1002/ppp.690, 2010.

Vonder Mühll, D., Hauck, C., and Lehmann, F.: Verification of geophysical models in Alpine permafrost using borehole information, Ann. Glaciol., 31, 300-306, doi:10.3189/172756400781820057, 2000.

Wirz, V., Beutel, J., Gruber, S., Gubler, S., and Purves, R. S.: Estimating velocity from noisy GPS data for investigating the temporal variability of slope movements, Nat. Hazards Earth Syst. Sci., 14, 2503-2520, doi:10.5194/nhess-14-2503-2014, 2014.

Zenklusen Mutter, E. and Phillips, M.: Active Layer Characteristics At Ten Borehole Sites In Alpine Permafrost Terrain, Switzerland, Permafrost Periglacial Process., 23, 138-151, doi:10.1002/ppp.1738, 2012a.

Zenklusen Mutter, E. and Phillips, M.: Thermal evidence of recent talik formation in Ritigraben rock glacier: Swiss Alps, 10th International Conference on Permafrost, Salekhard, Russia, 479-483, 2012b.

Zenklusen Mutter, E., Blanchet, J., and Phillips, M.: Analysis of ground temperature trends in Alpine permafrost using generalized least squares, J. Geophys. Res., 115, F004009, doi:10.1029/2009JF001648, 2010. 